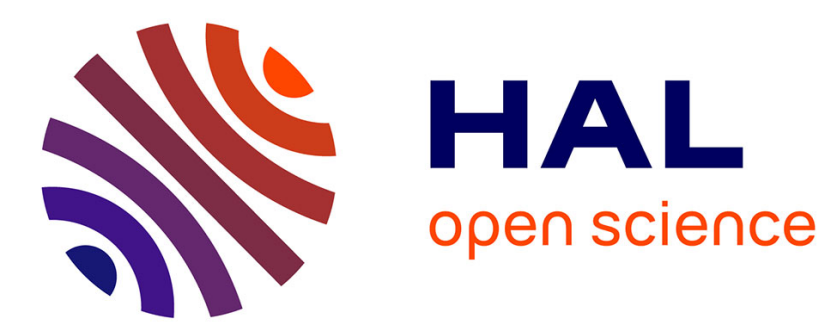

\title{
Toward a Digital Hermeneutics
}

Alberto Romele

\section{To cite this version:}

Alberto Romele. Toward a Digital Hermeneutics. Techné: Research in Philosophy and Technology, 2016, 20 (1), pp.76-83. 10.5840/techne20162013 . hal-01298506

\section{HAL Id: hal-01298506 https://hal.science/hal-01298506}

Submitted on 6 Apr 2016

HAL is a multi-disciplinary open access archive for the deposit and dissemination of scientific research documents, whether they are published or not. The documents may come from teaching and research institutions in France or abroad, or from public or private research centers.
L'archive ouverte pluridisciplinaire HAL, est destinée au dépôt et à la diffusion de documents scientifiques de niveau recherche, publiés ou non, émanant des établissements d'enseignement et de recherche français ou étrangers, des laboratoires publics ou privés. 


\title{
Toward a Digital Hermeneutics
}

\author{
Alberto Romele
}

Review of Virtual Worlds as Philosophical Tools: How to Philosophize with a Digital Hammer, by Stefano Gualeni (Palgrave Macmillan, 2015). 194 pp., ISBN: 978-1137521774

For some years, academics have been discussing 'the end of the virtual.' According to some of them, this means that the old economic and political forces are succeeding into 'dividing and conquering' the 'spaceless space' of the Internet as Manuel Castells called it. Recent initiatives of the European Commission such as the 'Right to be forgotten' ruling demonstrate that the Internet is increasingly becoming regionalized. According to the ruling, people have the right, under certain conditions, to ask search engines like Google to remove results for queries that include their name. As a consequence, today research results within European countries might always be different than those made within other states.

Moreover, people today are disposed to pay for services and products online that were considered free until few years ago. For instance, Google has recently released Google Contributor, an experimental service that allows users to pay in order to have less or no ads on their favorite websites. Music file sharing has been used in the past to show the dynamics of gift giving online; the current success of commercial music streaming services like Spotify is illustrative of the end of such a 'cyberutopia' (Romele and Severo 2016). Finally, the giants of the Internet are now able to collect, aggregate, and monetize all sorts of digital traces we leave behind us. In some cases, these traces are ceded to security agencies of nation states like the American NSA, as revealed by Edward Snowden in 2013.

According to other scholars, the end of the virtual has more to do with the emergence of an always already connected environment that Luciano Floridi has called 'infosphere.' In this environment, the frontiers between human intentions and their surroundings are softened. The Internet of things, the augmented reality, the diffused traceability, etc. are optimizing our relations with the others, the world, and ourselves. Let us consider, for example, the movement of the 'Quantified Self.' Ten, fifteen years ago, a series of ritual actions used to mediate access to the Internet: turn the computer on, wait, turn the modem on, wait, sit down on a chair in front of a computer's screen, wait, launch the browser, wait, etc. Thanks to all sorts of mobile devices and connected objects that characterize our present, which will certainly be part of our future, we are 
spending most of our life online. 'Onlife' is another of Floridi's fancy expressions (Floridi 2015). In this sense, it is not the 'real' that conquered the 'virtual,' but the other way round.

\section{Virtual Worlds as Living Metaphors}

Compared with these two perspectives (balkanization of the Internet on the one hand, digitalization of our lives on the other hand), Stefano Gualeni takes what at first glance might be considered a half step back. Indeed, he implicitly defends the idea that the frontiers between the 'real' and the 'virtual,' or between actual and virtual digital worlds in his terminology, are permeable, but nonetheless they must be maintained. This is mainly due to the fact that the author, who is both a philosopher and a computer designer, limits his analysis to the domain of non-immersive video games, in which the screen and the input devices still represent rather solid barriers between real and virtual worlds. In reality, as I will suggest below, Gualeni takes a step forward, toward a hermeneutical approach to digital technologies that might be extended to the experiences of telepresence, as he calls them, i.e. those technologies enabling information exchanges and different degrees of agency (43-44).

The main thesis of the book is that computer games, albeit without radically subverting human experiences and thoughts, can cause their 'distortion, extension, and fragmentation.' In other words, the virtual digital worlds exert a power of 'reconfiguration' over human ways of being in the world, with the others, and with oneself. The term 'reconfiguration' refers to the theories of the French philosopher Paul Ricoeur on the heuristic function of metaphor and narrative. In The Rule of Metaphor (Ricoeur 2003), he refused both the more classic 'cosmetic' idea according to which metaphors just have the function of embellishing stories; and the Nietzschean and postmodern idea for which there is nothing but metaphors, and that the reality itself, together with its concepts, is a 'white mythology,' that is to say a metaphor whose nature has been forgotten. In the first volume of Time and Narrative (Ricoeur 1990), thanks to the notion of threefold mimesis, Ricoeur discusses the impact of stories, fictional and historical, told and read, on the temporal character of human experience. Finally, the stories become fully effective through the concept of narrative identity, developed in the third volume of Time and Narrative and in the fifth and sixth study of Oneselfas Another (Ricoeur 1992): since human beings constitute a part of their self in relation to the stories they tell and read, narrations have a relevance that go far beyond entertainment and mere distraction. It is not by chance then that Gualeni abundantly refers to Ricoeur in chapter VII of the book, when he defines the virtual digital worlds as metaphors that 'have the power to disrupt and change fundamental attitudes and beliefs about the world and can thus be used persuasively in the 
pursuit of institutional as well as artistic, philosophical, critical, and personal goals' (133). He also refers to Lakoff and Johnson's notion of metaphor's 'ontological function,' i.e. 'its formative role in shaping individual thought and framing social interaction' (136).

In Gualeni's opinion, as he argues in the central chapters (III-IV-V), computer games go even further in their heuristic function than the more classic cultural objects such as books. Firstly, because their semantics is not confined to the spoken and written words; they are multimedial, i.e. they combine words with moving images, and sounds. Secondly, in terms of automation and immersion, computer games have popularized and improved multilinearity and interactivity made by literary and artistic avant-gardes during the last century such as Raymond Queneau's 1961 book A Hundred Thousand Billion Poems, Surrealist collages, and Dada assemblages. Finally, in the traditional media, virtual worlds, that is to say those worlds bursting into the continuum of our 'native world,' are experienced 'on the basis of subjective imagination and interpretation.' Computer games, by contrast, provide 'experiences that emerge from establishing relationships with an objective world' (62); 'traditional media cannot provide the effective materialization of worlds and, as such, cannot be expected ever to engage a subject at the ontological level' (67).

It is noteworthy that Gualeni distinguishes here four levels on which computer games have or might have an effect on human existence. First, they affect the practices and cognitions of the users. Second, they influence the practices and the cognitions of the game designers themselves. Incidentally, this point has often been neglected in the philosophical hermeneutic tradition. Third, they help in concretizing and broadly diffusing those philosophical concepts that otherwise would remain too abstract. As examples, he takes two 'philosophical video games' he personally designed and developed, Gua-Le-Ni and Necessary Evil. The former aims to playfully negotiate David Hume's notion of complex ideas; the latter offers a critique of 'player-centrism,' which is an integral feature of classic video games. It wants 'to make the player experience the feeling of marginality and to reveal experientially what a virtual world feels like when this world is designed around someone else's point of view and someone else's goals and desires' (89). Fourth, virtual digital worlds can make accessible to humans those experiences that are radically non-human. In response to Thomas Nagel's argument, according to which human beings cannot share non-human experiences such as those of bats, Gualeni created Haerfest, a video game, whose objective is precisely to show, at least in part, what it is like to be a bat for a bat.

\section{Philosophical Heritages}


Gualeni's reflections are based on a twofold philosophical heritage. First of all, as he makes explicit in chapter I, they have a source of inspiration in Don Ihde's and Peter-Paul Verbeek's 'postphenomenology' or 'material hermeneutics.' Postphenomenology generally argues that technological artifacts have a mediating role in the relation between human beings and the world. Moreover, it claims that the subject and the world are not given a priori, but they constitute themselves at the precise moment of the relation. From this, one can infer that the technological artifacts, both when they are conceived and forged, and when they are used, have a central role in the constitution of the subjects and the world. The designer realizes in the objects her own ethos and sensitivity. The user finds in the artifacts an occasion for thinking and acting differently. Gualeni applies postphenomenology to the computer games. Following Ihde's distinction between four Itechnology-world relations, one might say that computer games establish 'alterity relations' that become 'hermeneutic relations' when the designer or the player starts to reinterpret herself and her own actual world in the light of the possibilities offered by digital simulations. For Gualeni, a sort of 'caring society' between players and designers exists, '[a] community of players-explorersdesigners-makers that is willing to play, discuss, and participate in the refinement of an experience' (78). The designer, then, is not a 'demiurge, but rather an earthly scenographer, someone who is responsible for setting up constraints and affordances that will be freely appropriated by the actors (the players) during the play' (96).

Like all postphenomenologists, Gualeni attributes great importance, especially in chapter II, to Heidegger's philosophy of technology. In What Things Do (2005), Verbeek criticized the later Heidegger's writings on technology for being too abstract and monolithic, although he has also censured those critics of Heidegger who have been too abstract and monolithic in their own critiques. Verbeek proposes to turn the attention toward the early Heidegger's considerations on the technical artifacts. Gualeni claims, by contrast, that 'the second phase of Heidegger's thought is - at least in a general sense - more promising than the first in terms of its less monolithic approach to the projectual possibilities of our technically-mediated being-in-the-word' (38). First, since for the later Heidegger human artifacts can establish new worlds and the emergence of different worldviews. Second, because the German philosopher recognized the 'possibilities for overcoming Western thought as latent in the depth of the technological mindset' (39). Yet, according to Gualeni, the overcoming of the classic ontologies can be concretely pursued, and not, as the later Heidegger did, simply prophesized.

Furthermore, the fact remains that the second phase of Heidegger's philosophy is deeply anti-humanist. For this reason, and this is the second philosophical heritage of Gualeni's book, the 
author refers to Helmuth Plessner's anthropology in chapter VI. He shares with Plessner the idea that human beings are 'artificial by nature.' He also uses Plessner's distinction between three levels of organic. Human beings are characterized, compared to plants and animals, by an 'eccentric positionality, i.e. the coexistence of two connected nuclei, one within the body, and the other, that makes self-reflection possible, outside. The author integrates this theory with the insight offered by the Dutch philosopher Jos de Mul, according to which the structural hybridization of human biology and interactive digital technologies capable of displacing human cognition cause the emergence of an additional positional form: 'Poly(ec)centric positionality,' an expression indicating that digital technologies not only displace the human intentional boundary-realization, but also multiply it (115).

\section{Transductions}

As I said, Gualeni's book might be considered as the first step toward a digital hermeneutics. With this term, I propose to indicate an approach characterized by three elements. First of all, a problematization of the presumed homology between the world and its digital representations - a position that has been defended, for instance, by Bruno Latour and his collaborators on several occasions (e.g. Latour et al. 2012). Another French philosopher, who is experiencing an increasing posthumous recognition, Gilbert Simondon, refers to 'transduction' as a process of thinking consisting of establishing similarities among relations. According to him, however, this process cannot be assimilated to translation - which, incidentally, is an important concept for actor-network theory - since it is not based on identity, but rather on the differences it aims to explain (Simondon $2005,108)$. In these terms, digital hermeneutics would deal with analogies and differences between actual and virtual digital worlds, with (the limits of) their mutual effectiveness.

In order to do this, and this is the second element characterizing a hermeneutic approach toward digital technologies, it is necessary to overcome the ruinous alternative between truth and method in the field of the digital studies. Behind the unifying etiquette of 'digital humanities,' there is often either a technically-mediated approach to some cultural objects, or a sort of humanist critique to digital technologies - 'le numérique,' as French academics commonly subjectivize the adjective 'digital.' Digital hermeneutics should instead articulate an object-oriented attitude toward specific digital objects with an interest for the existential and ontological consequences of their production and use.

Both these elements are well presented in Gualeni's book. He considers the mutual interactions between actual and virtual digital worlds, but he does not confuse them; he develops 
existential and ontological reflections on the basis of his technical competencies and his passion for computer games. Considering all this, it is such a pity that Gualeni limits his analysis to the context of video games, without considering other digital technologies such as social media. Facebook, for instance, has a great reconfiguration power over the narrative identities of its users (Romele 2013).

Yet digital hermeneutics should be also made of a third element, which seems to be missing, at least in great part, from Gualeni's reflections. I refer to a 'pharmacology' of digital technologies, i.e. an analysis revealing both their benefits and risks. This term has been recently used by Bernard Stiegler, who borrowed it from Jacques Derrida. Interestingly, before Ihde and Verbeek, the Hungarian philologist Peter Szondi had already used the term 'material hermeneutics' for defining his approach to literary texts. On the one hand, he wanted to stress the necessity of an objectoriented research on specific texts, conducted with the most rigorous methodologies. On the other hand, he aimed to highlight the importance of a critique of ideology of their context of production and fruition. Szondi had in mind the thesis of the Frankfurt School's representatives Theodor W. Adorno and Walter Benjamin, plus the thought of his compatriot György Lukács. Now, it is precisely this critical attitude that Gualeni seems almost entirely to neglect; an attitude that, in my opinion, must not necessarily be influenced by the theories of the Frankfurt School.

Gualeni refers to game designers and users as members of a (potentially) enlightened community, which in the end risks being no less exclusive than Plato's Academy. He forgets then to discuss the risks related to any form of elitism and communitarianism. He also neglects the fact that most of the computer games are not created for liberation purposes, but for economic interests. He strongly believes in the democratic force of virtual digital worlds. He is partly right in claiming that video games have popularized experiences that were reserved until thirty years ago for the cultural elites. But he does not consider the fact that computer games also generate new types of divides, between elderly and young people, between rich and poor, etc. Paradoxically, since most of human contemporary cultures are still writing-based, classic forms of mediation might be considered more 'democratic' than the new digital ones. Such a critique would be all the more urgent when one considers other digital technologies like social media. Indeed, most of them do not promote any sort of informed use, but rather the opposite in this case. Gualeni counterbalances his optimism in some passages, as when he claims that 'videogames, like any form of mediation, can disclose reality in specific ways that are always both revealing and concealing' (94), which are nonetheless too few and too short. Moreover, Gualeni seems to implicitly believe that philosophy is critical per se, and always bearer of positive changes and values. Unfortunately, in the course of history, philosophy has often been used for maintaining the status quo as well. 
Finally, the statement according to which only digital technologies provide 'effective materializations of worlds' is rather problematic. He does not consider, for instance, the virtual analogic worlds created by cinema, which are no less concrete, although certainly less interactive. He does not reflect on the fact that literary worlds overcome the limits of 'subjective imagination and interpretation' as long as they are the objects of public and social debates, as long as they are part of a specific literary genre, and of a socially shared tradition, which can be defended or contested.

As I said, Virtual Worlds as Philosophical Tools has the merit to pave the way for a hermeneutic approach to digital technologies. It is now the task of Gualeni himself, or of someone else's, to walk this path. This means both to approach also different kind of digital technologies, and to definitely renounce to any kind of romanticism.

\section{References}

Floridi, Luciano, ed. 2015. The Onlife Manifesto. Being Human in a Hyperconnected Era. London: Springer.

Latour, Bruno, Pablo Jensen, Tommaso Venturini, Sébastian Grauwin, and Dominique Boullier, 2012. "The Whole is Always Smaller than Its Parts. A Digital Test of Gabriel Tarde's Monads." The British Journal of Sociology 63(4): 590-615.

Ricoeur, Paul. 1990. Time and Narrative, Volume 1. Chicago: The University of Chicago Press.

Ricoeur, Paul. 1992. Oneself as Another. Chicago: The University of Chicago Press.

Ricoeur, Paul. 2003. The Rule of Metaphor. London: Routledge.

Romele, Alberto. 2013. "Narrative Identity and Social Networking Sites." Etudes Ricoeuriennes/Ricoeur Studies 4(2): 108-22.

Romele, Alberto and Marta Severo. 2016. "The Economy of the Digital Gift. From Socialism to Sociality Online." Theory, Culture \& Society, online first, http://tcs.sagepub.com/content/early/2016/01/20/0263276415619474. 
Simondon, Gilbert. 2005. L'individuation à la lumière des notions de forme et d'information, Grenoble: Millon.

Verbeek, Peter-Paul, 2005. What Things Do. Philosophical Reflections on Technology, Agency, and Design. University Park, Pennsylvania: Pennsylvania University Press. 